\title{
THE EMIGRATION OF MUSLIMS FROM THE GREEK STATE IN THE 19TH CENTURY. AN OUTLINE ${ }^{1}$
}

\author{
KRZYSZTOF POPEK
}

\begin{abstract}
AвSTRACT. Modern Greek statehood began to take shape with the War of Independence that broke out in 1821 and continued with varying intensity for the next years. As a result of these events, the Greeks cast of the foreign rule, which for many not only meant separation from the Ottoman Empire, but also the expulsion of Muslims living in these lands. During the uprising, about 25000 Muslims lost their lives, and a similar number emigrated from the territory of the future Greek state. The next great exodus of Muslims from Greek lands was related to the annexation of Thessaly by the Hellenic Kingdom, which was to a larger extent spread over time. Since the region was incorporated into Greece until the beginning of the 20th century, the 40000 -strong Islamic community had virtually disappeared.
\end{abstract}

Author: Krzysztof Popek, Jagiellonian University, Faculty of History, World Contemporary History Department, Gołębia st. 13, 31-007 Cracow, Poland, popek.kj@gmail.com, ORCID ID: http://orcid.org/0000-0001-58645264

Keywords: Greece, 19th century, Muslim minority, migrations, Thessaly, Greek War of Independence Balcanica Posnaniensia. Acta et studia, XXVII, Poznań 2020, Wydawnictwo Wydziału Historii UAM, pp. 97122, ISBN 978-83-66355-54-5, ISSN 0239-4278. English text with summaries in English and Polish.

doi.org/10.14746/bp.2020.27.7

\section{INTRODUCTION}

Although Greece itself does not want to be treated as one of the Balkan countries, the Greek experience of the period of building its own nation-statehood is characteristic of this region. The Kingdom of Greece was created as a result of the separation of lands from the Ottoman Empire, and then annexing other territories that were not only inhabited by the Hellenes, but also by other ethnic and religious groups. Muslims played a key role among them not only the former masters of these lands, closely related to the system of power of the Ottoman Empire, but also simple farmers or city dwellers. Muslims had settled there during the period of the domination of the Islamic

1 Research presented in this article was financed by the grant of the Polish National Science Center: The Balkan migration processes in the 19th century. Cases of Bulgaria and Serbia (2017/25/N/ HS3/00576). 
empire; in other cases, their ancestors were local people who had accepted the faith of the rulers. The formation of the Greek state, whose relationship with the Greek nation and the Orthodox Church was unquestionable, was parallel to the disappearance of the Muslim community from the area. The phenomenon had a place in the whole of South-Eastern Europe: Between 1821 and 1922, about 5 million Muslims migrated from the Balkan Peninsula and the coast of the Black Sea; in 1878-1913, 1,7-2 million people left Turkey-in-Europe mostly because of the political changes which processed in the region ${ }^{2}$.

The article analyses the political factors which influenced the Muslim migration from Greek through the British diplomatic sources. While this subject is well described in the context of the last stage of this process, i.e. the population exchange of $1923^{3}$, the earlier period, related to the War of Independence and the annexation of Thessaly in 1881, has not been fully researched in historiography ${ }^{4}$.

British diplomatic materials are a valuable source to research the history of Greece in the 19th century. London was strongly interested in the situation of Greeks since the War of Independence: Great Britain was one of the three Great Powers, next to France and Russia, which led to the emergence of the modern Hellenic state and announced themselves as the defenders of Greek independence, which could be interpreted as a form of semi-protectorate (after all, the British invoked this right during the First World War). The keen interest was linked to the strategic geographic location of Greece, on routes leading to British colonies. British consulates functioning at that time throughout the Balkans collected detailed information not only on the geopolitical situation in the region but also on the internal affairs of states and provinces.

Before the outbreak of the War of Independence, the territory of the future Kingdom of Greece was inhabited by 63615 Muslims, constituting about 7\% of the population. Some researchers quote a larger number 90 830, i.e., about $10 \%$. Most Muslims lived in the Kyparissi area of the Peloponnese (about 70\%), Euboea (15\%), and Attica $(10 \%)^{5}$. As with the Muslims living in other areas of the Ottoman Empire,

2 K. Karpat, Studies on Ottoman social and political history, Leiden-Boston-Köln 2002, p. 321.

3 See O. Y1ldırım, Diplomacy and displacement reconsidering the Turco-Greek exchange of populations, 1922-1934, New York-London 2006; Crossing the Aegean: The Consequences of the 1923 GreekTurkish population exchange (studies in forced migration), Providence 2003; D. Pentzopoulos, The Balkan exchange of minorities and its impact on Greece, London 2002; R. Hirschon, Crossing the Aegean: an apraisal of the 1923 compulsory population exchange between Greece and Turkey, New York-Oxford 2003; G. Kritikos, State policy and urban employment of refugees: the Greek case (1923-30), „European Review of History: Revue Européenne d'Histoire", 2000, vol. 7, no. 2, p. 189-206.

${ }^{4}$ N. Immig, Ottoman past, national discourses on Muslim populations and their architectural legacy in Arta and Thessaly, in: Balkan Nationalism(s) and the Ottoman Empire, vol. 1: National Movements and Representations, ed. D. Stamatopoulos, Istanbul 2015, p. 144-145. The only synthetic book on that topic is prepared by Paraskevas Konortas, Les musulmanes de Grèce entre 1821 et 1912, Paris 1980.

${ }^{5}$ М. Паларе, Балканските икономики 1800-1914 г. Еволюиия без развитие, прев. М. Кондакова, София 2005, p. 30; Н. Тодоров, Балканският град XV-XIXвек. Сочиално-икономическо и демографско развитие, София 1972, p. 331-332; S. Katsikas, Millet legacies in a national environment: political elites 
the main paradigm of Muslim identity in Greece was religion intertwined with a sense of submission to the Sultan. Self-identification had been shaped in a similar way in the Byzantine Empire, the „Romeis” had not necessarily spoken Greek, and this community had been formed by the Emperor's Orthodox subjects. Among the Muslims who lived next to Greeks in the Ottoman period, there was a Turkish-speaking population (both immigrants and assimilated), Greek-speaking (e.g. in Peloponnese, Central Greece, and Thessaly; in Crete and in Western Macedonia, it was called Valaades), Slavic-speaking (the Pomaks, although this group lived mainly in Macedonia and Western Thrace), Albanian-speaking (living in various parts of the Greek lands, in compact groups in Epirus and southwestern Macedonia), Ladino-speaking Islamized Jews (called „Domnes”, in Thessaloniki or Smyrna), Greek-speaking nomads - the Karakachan (Thessaly, Western Thrace, and Macedonia), and the Roma, often excluded from umma (called Athinganoi or Tsigganoi). They were mainly Sunnis, although Shiites and heterodox Sufis also lived in these areas (the Bektashi community functioned in the Kingdom of Greece until 1923). The Greek state basically ignored these differences, treating them equally as Muslims, and often referred to them simply as „Turks” or „Ottomans"6.

\section{THE GREEK WAR OF INDEPENDENCE AND ITS AFTERMATH}

Modern Greek statehood began to take shape with the War of Independence that broke out in 1821 and continued with varying intensity for the next years. As a result of these events, Greeks became independent from the reign of the Sultan, which for many not only meant separation from the Ottoman Empire, but also the expulsion of Muslims.

The opinions in the literature that this movement in Greece was unconditionally aimed at the entire Islamic population living in these areas are not entirely true ${ }^{7}$, the insurgents initially cooperated with the Albanians of Ali Pasha from Ioannina, who sent his troops to the Peloponnese under the command of Elmaz Medzos. This alliance, however, did not provide protection for the Muslims in Greece. The revolution itself was a decentralized movement, without a central leadership that could impose specific rules on everyone and provide protection to Muslim civilians as Albanians

\footnotetext{
and Muslim communities in Greece (1830s-1923), in: State-nationalisms in the Ottoman Empire, Greece and Turkey: Orthodox and Muslims, 1830-1945, eds. B. Fortna, S. Katsikas, D. Kamouzis, P. Konortas, Abingdon-New York 2013, p. 48.

6 Е. Иванова, Ислямизирани Балкани. Динамика на разказите, София 2014, p. 66; D. Christopoulos, Islam and state religion in Greece: from the formation of the 'Greek-Orthodox Genos' to the era of migration, in: Strengthening religious tolerance for a secure civil society in Albania and the southern Balkans, eds. J. Pettifer, M. Nazarko, Amsterdam-Berlin-Oxford-Tokyo-Washington 2007, p. 67.

7 Cf. Дж. Маккарти, Смърт и изгнание: Етническото прочистване на османските мюсюлмани (1821-1922), прев. К. Панайотова, София 2010, р. 23-24.
} 
had naturally expected. Such assurances could only be obtained from their immediate comrades-in-arms. As a result, there were situations in which the armed men of Medzos, who had fought alongside the insurgents, died at the hands of the Greek population when they separated from their unit ${ }^{8}$. Even among their Christian comrades, they heard offensive words against Muslims (We will cut off all these pig snouts!), which caused tensions between Greeks and Albanians. In October 1821, Ali Pasha sent his envoy, Thair Abashi, to Missolonghi and Vrachori (Agrinio) to check on the cooperation with the „Romeis”: When he got there, he found Turkish women baptized, local Turks killed, mosques ruined and profaned. When the information about Medzos' soldiers who died at the hands of Greeks reached him, he decided to secretly communicate with the Sultan regarding a settlement and support in suppressing the revolution. Finally, at the end of November, cooperation with the Greeks was ended, and the troops of Elmaz Medzos changed sides to Hurshid Pasha's. The cooperation of „Lion of Ioannina” with the insurgents was the last factor that, even if only partially, protected Muslim civilians from the violence of the insurgents?.

Following the outbreak of the Peloponnese uprising, Ottoman forces initially held a number of fortresses: Tripoli, Nafplio, Monemvasia, Koron, Modon, Navarino, and Patras, where local Muslims took refuge. When garrisons fell, there were pogroms. In August 1821, Navarino capitulated - the Greeks promised to spare Muslim civilians and let them leave the city, however, they did not keep the contract and murdered nearly 3000 people. The conquest of Tripoli by Greeks in October led to the deaths of almost all Muslims in the fortress ${ }^{10}$. At the end of 1821, after a long siege, the insurgents seized the Acropolis - the act of surrender signed under the guarantees of Western diplomats assumed that 1200 Muslim civilians had the right to stay in Athens or leave for Asia. However, news of the Ottoman offensive from Euboea made Greeks break the agreement and they began killing prisoners, including women and children. European diplomats organized the rescue of four hundred Muslims who were transported to Smyrna. The property left behind by the „Turks” was confiscated - half was taken by representatives of the new authorities, who organized auctions to arm their troops, and the other half was seized by the insurgents who took the city ${ }^{11}$. When Greeks conquered Nafplio in November 1822, English sailors helped Muslim civilians evacuate to avoid a repetition of the Tripoli situation ${ }^{12}$. Similar events took place in Peloponnesian villages: In 1824, in Meligalas, a small town in Messenia, lo-

8 J. Makrijanis, Topornym piórem. Pamiętniki z powstania greckiego i pierwszych lat wolności, thum. i red. M. Borowska, Warszawa 2010, p. 145-147.

9 Ibidem, p. 157-161.

10 A. Bojarski, Powstanie Greków w latach 1821-1829, Warszawa 2011, p. 53-55; J. Bonarek, T. Czekalski, S. Sprawski, S. Turlej, Historia Grecji, Kraków 2005, p. 450.

11 J. Makrijanis, op. cit., p. 208-209; A. Bojarski, op. cit., p. 75.

12 Ibidem, p. 108; S. Bandžović, Bošnjaci i deosmanizacija Balkana: muhadžirski pokreti i pribježišta ,sultanovih musafira” (1683.-1875.), Sarajevo 2013, p. 195-196. 
cal Greeks killed their Muslim neighbours and took their possessions ${ }^{13}$. During only March and April 1821, a total of 15000 Muslims were killed and 3000 Muslim houses were destroyed, which was accompanied by a wave of escapes. Revolutionaries did not see the difference between Turkish-speaking and Greek-speaking Muslims, and additionally, all Islamic symbols were removed. Many „Turks” were forced to accept Christianity: Some, not wanting to leave, but anticipating the arrival of the insurgents and did so seemingly voluntarily ${ }^{14}$. According to the American researcher Justin McCarthy, as a result of these expulsions and pogroms as early as in April 1821, only 20000 Muslims remained on the area of the later Kingdom of Greece out of 60000 who had lived there before the outbreak of the uprising ${ }^{15}$.

Historians recognize the Greek War of Independence as the first „,modern revolution in the Balkans", with all the hallmarks of later anti-Ottoman wars and uprisings involving ethnic cleansing and Muslim resettlement ${ }^{16}$. Comparing the Greek War of Independence to the Great French Revolution, Dimitris Christopoulos emphasizes that the main difference between these events was that "anyone could become French, as long as he shared the ideals of the French revolution and the nation. Greeks, however, assumed that Turks could not become Greeks unless they accepted Christianity ${ }^{17}$. Even the declarations of tolerance were accompanied with the acceptance of violence. Ioannis Kapodistrias expressed the conviction that in the new Greece it would be possible for Greeks and Muslims to coexist, as long as Christians would gain numerical and political advantage over the ,Turks”. The first Greek president recognized that as long as Muslim accepted their second-class status and Greek domination, they would not have to leave ${ }^{18}$. Many of the assurances regarding the respect of Muslims' rights were dictated solely by diplomatic issues. This is how the declarations of Kapodistrias during negotiations with the world powers in 1830 should be understood, in which he assured that the Greek government would comply with all laws regarding the property rights of Muslims in Greece and guidelines in this regard ${ }^{19}$.

Greeks emphasized that the violence against Muslims was a form of retaliation, or even self-defence, especially against the reports of pogroms against Greeks in Constantinople, Smyrna, and Chania. In the regions controlled by the insurgents, there was a fear of Muslims who remained there as the insurgent and author of mem-

13 J. Makrijanis, op. cit., p. 271.

14 T. Sahara, Forced ethnic migrations and modernity in the Balkans, in: Forced ethnic migrations in the Balkans: consequences and rebuilding of societies, ed. E. Popova, M. Hajdinjak, Sofia-Tokio 2006, p. 26.

15 Дж. Маккарти, op. cit., p. 20-21.

16 N. Immig, The „New” Muslim minorities in Greece: between emigration and political participation, 1881-1886, „Journal of Muslim Minority Affairs” 2009, vol. 29, no. 4, p. 512.

17 D. Christopoulos, op. cit., p. 72.

18 Abstracts of Proceedings in the Greek Question, to the Conclusion of the Treaty between England, Russia, and France, 1827-1831, FO 198/1/48 (Part V).

19 Ibidem, 26 (Part VI). 
oirs from that period Yannis Makriyannis wrote: There were still many Turks there, just waiting (...) to attack the inhabitants ${ }^{20}$. The violence escalated after the massacre on Chios in April 1822, during which 25000 out of 100000 Greeks living on the island were murdered, and 45000 women and children were sold into slavery; the remaining Christians were forced to flee. The turning point of the uprising was the capture by the Ottoman army of the Missolonghi fortress in 1826. Against the conditions of surrender, the soldiers murdered all Greeks capable of carrying weapons. Four thousand women and children were taken prisoner and taken to Egypt; 1500 people fled from the fortress. The fate of Missolonghi had important impact on the insurgents' way of thinking. For the first time in the negotiations, Greeks made a request to the Sublime Porte that the condition for concluding peace would be the resettlement of the entire Muslim population from the Greek territories, and the Muslims were additionally to be deprived of their property. The same year, in August, when Egyptians entered Athens, the Greek inhabitants of the city decided to flee, mainly to nearby Salamis. Only 1400 Greeks remained there, mainly around the Acropolis ${ }^{21}$. Ibrahim Pasha, who pacified the main centres of the insurrection, heading the Egyptian forces, assumed mass deportation of insurgents from Greece to Africa and the settlement of these lands by Muslims. ${ }^{22}$ The Ottoman authorities, who called on the Sultan's Islamic subjects to defend the empire and their religion, also contributed to the escalation of violence against civilians ${ }^{23}$.

Table 1: Population of the areas covered by the Greek uprising in 1821-1828

\begin{tabular}{|c|c|c|c|c|c|c|}
\hline & \multicolumn{3}{|c|}{1821} & \multicolumn{3}{c|}{1828} \\
\hline & Christians & Muslims & In total & Christians & Muslims & In total \\
\hline $\begin{array}{c}\text { Central } \\
\text { Greece }\end{array}$ & 247850 & 20865 & 268715 & 172850 & 11450 & 184300 \\
\hline Peloponnese & 468000 & 42750 & 500750 & 400000 & 0 & 400000 \\
\hline Islands & 169300 & 0 & 169300 & 169100 & 0 & 169100 \\
\hline In total & 875150 & 63615 & 938765 & 741950 & 11450 & 753400 \\
\hline
\end{tabular}

Source: Statistic Tables of Western Greece, Therapy, and Epirus, communicated by Mr. Tricoupi in his Note dated 30.09.1828, FO 352/22/5/26; Н. Тодоров, Балканският град XV-ХIX век. Социално-икономическо и демографско развитие, София 1972, p. 313; K. Tsitselikis, Old and new Islam in Greece. From historical minorities to immigrant newcomers, Leiden-Boston 2012, p. 31-32.

20 J. Makrijanis, op. cit., p. 163.

21 A. Bojarski, op. cit., p. 90-95, 174-175, 184, 192.

22 Abstracts of Proceedings, FO 198/1/38-39 (Part IV).

23 Ibidem, FO 191/1/18-19 (Part V). 
During the Greek War of Independence, the number of inhabitants in the areas affected by these events decreased by 185365 people. Muslims, who constituted nearly $7 \%$ of the population of the area of the later Kingdom, in the vast majority (about $80 \%$ ) left the area or were killed. During the War of Independence, around 25000 Muslims lost their lives, and twice as many emigrated north or to Anatolia. Not only was the Islamic community affected by this conflict, it was a tragic time for the entire civilian population. Up to $130000 \mathrm{Greeks}$ were killed, forced to flee, or taken as slaves ${ }^{24}$. Greek people came to the deserted cities, taking over the estates abandoned by the Muslim population. New residents came from the islands (e.g. Hydra, Spetses) and Peloponnesian villages ${ }^{25}$.

During the Ottoman period, Muslims controlled about $50-75 \%$ of mainland Greece's arable land, even though they were a relatively small community. It belonged mainly to the beys who lived in cities or fortified estates called $k o n a k \mathrm{~s}^{26}$. During the revolution, Muslim private land and Ottoman state estates were occupied by the participants of the uprising, as well as by Greek peasants who were not involved in fighting against the „Turks”, but benefited from the anarchy. All his happened with the consent of the insurgent authorities. In 1822 the National Assembly announced the expropriation of all Muslims in favour of the Greek state except for the people of Euboea, and in April 1826, a resolution was issued under which „Turks" could not own any property in the territory of free Greece. The issue of Muslim property was the subject of many years of negotiations, lasting in fact from 1827, which involved the powers, the Sublime Porte and, to a limited extent, Greeks. There was no doubt that the Turks [i.e. the Ottoman authorities] must not retain any property in Greece, including fortresses, and they cannot have any influence on the Greek administration ${ }^{27}$. During the negotiations carried out (among others) in December 1828 on the island of Poros, the prospect of compensation for expropriation, related procedures, and the appointment of a commission to supervise the departures of Muslims from Greece were discussed ${ }^{28}$.

The final decisions on the fate of Muslims in Greece were made during the London Conference in 1832, and they were largely based on the protocols issued in the years 1828-1830. The property rights of Muslims who wished to remain in the territory and become Greek citizens were formally guaranteed. It was established that the Muslims who expressed their readiness to leave, had one year to sell their property and emigrate. These regulations were supposed to concern about 8000 Muslims who still

24 W. Holt, The Balkan reconquista and Turkey's forgotten refugee crisis, Salt Lake City 2019, p. 77; Н. Тодоров, ор. cit., p. 331-332.

25 A. Bojarski, op. cit., p. 108.

26 S. Katsikas, Millet legacies, p. 48.

27 Abstracts of Proceedings, FO 198/1/21 (Part III), 14-15 (Part VI); K. Tsitselikis, Old and new Islam in Greece. From historical minorities to immigrant newcomers, Leiden-Boston 2012, p. 13.

${ }^{28}$ Abstracts of Proceedings, FO 198/1/51 63 (Part V); Translation of Protocol of the Conference Held at Poros Between the Representatives of Great Britain, France, and Russia, 12.12.1828, FO 476/24/2223, 36-38. 
lived in this area in December 1828, mainly in Euboea, Zetounion, and Ypati ${ }^{29}$. All the waqfs were to become the property of the Greek state without any compensation, which naturally met with great resistance from the Sublime Porte. The powers, however, recognized that such estates were in fact similar in nature to state-owned areas in connection with providing for public service institutions. In the case of the lease of waqfs, the resulting liabilities were transferred to the Greek state. Importantly, there were no guarantees regarding the rights of Muslims in Greece. Such commitments were made only towards Catholics, and the provisions on the equality of all citizens were of a general nature ${ }^{30}$. One of the main decisions of the London Conference was delineating the boundaries of the new state. The principle was that the Greek population should be isolated from the Muslim one. The fact that the local people participated in the uprising was also treated as an argument in favour of including a given territory into the new state ${ }^{31}$. As early as 1830 , the Sultan issued a firman announcing that Muslims should prepare to sell their property and leave the Greek lands. As a result, the „Turks" who survived the uprising left with the retreating army and the last Ottoman officials ${ }^{32}$. To the few who remained and assumed Greek citizenship, were on February 22 (10 O.S.) guaranteed equal civil rights by King Otto, who also ordered the local administration (nomarchs) to give them special protection ${ }^{33}$.

The question of Muslims living in Greek territory was finally settled under the Treaty of Constantinople of 21 (9 O.S.) July 1832. The Sublime Porte announced in 1827 that Muslims would have to leave within three years without the right to claim property in the Greek-controlled area. At the same time, it was confirmed that all waqfs were brought under the control of the government in Athens. Only the „Turks" from Attica, Euboea, and the region of Thebes - the land that was only transferred to the control of the government in Athens under the provisions of the treaty, retained the ownership of property. For this property, their former owners were entitled to compensation, the amount of which was to be determined by a specially appointed arbitration committee ${ }^{34}$. In 1828 , it was assumed that these were areas inhabited only by Muslims, in Euboea, there were 28000 people, of which 4500 Muslims (before 1821 , there were 36000 inhabitants, including 7000 „Turks” ${ }^{35}$. Muslims from this territory, unlike those living in other areas of the newly-established Greece, were giv-

29 Ibidem, FO 476/24/22-23, 36-38.

30 Abstracts of Proceedings, FO 198/1/43 (Part V), 23, 28, 30 (Part VI).

31 Annèxe D au Protocole de la Conférence du 22 Mars, 1829, FO 476/24/20-22 (Protocols of Conference Held at London, Part III: Containing Protocols from March 22, 1829 to February 26, 1830, Inclusive).

32 Abstracts of Proceedings, FO 198/1/23 (Part VI).

33 K. Tsitselikis, op. cit., p. 33.

34 Arrangement between Great Britain, France, Russia, and Turkey, for the definitive settlement of the continental limits of Greece. Signed at Constantinople, 21st July, 1832, in: The Foundation of the modern Greek state. Major treaties and conventions (1830-1947), ed. Ph. Constantopoulou, Athens 1999, p. 37-44.

35 Protocol of the Conference Held at Poros, FO 476/24/32-33 (Annex C). 
en a year to decide whether to sell their property and leave or adopt Greek citizenship. A Greek-Turkish committee was set up to oversee the transactions and respect for property rights. In view of numerous problems, this body never finished its work. In view of the failure to settle this issue, in September 1837, a Greco-Ottoman agreement was concluded, under which the government in Athens was to buy all the property of Muslim emigrants in the Thebes region, and in March 1838, a second agreement was concluded concerning Muslim property in Euboea and Phthiotis. Greek authorities took this step under pressure from the three powers (Great Britain, France, Russia) who wanted to bring about the final settlement of matters related to Greek independence ${ }^{36}$.

Muslims tried to avoid expropriation by various means. The easiest way was to adopt Orthodoxy, which was associated with the hope of preserving one's property or obtaining compensation for losses incurred during the uprising in the future. It was a natural path for those kojabashas (representatives of the local Greek elite in the Ottoman period), whose faith before 1821 was manifested only by using Muslim names and going to mosques instead of churches. The choice between baptism and emigration undoubtedly qualifies as coercion. The remaining, isolated cases of conversion to Orthodoxy were related to mixed marriages between Christians and Muslims ${ }^{37}$. The government in Athens did not support Christianization. Both the state and the inhabitants of Greece hoped for taking over the former „Turkish” territories and did not want to give up the perspective of acquiring new property. For example, after gaining independence, the lands of the Greek government comprised between 1,5 and 2,5 million acres, and many of them were obtained at the expense of Muslims $^{38}$. Ioannis Kapodistrias postulated that these ,national lands" should be divided among the peasants in order to create a social base for the new state, which was blocked by political forces hostile to the president ${ }^{39}$. A large amount of ,post-Turkish" land has become a breeding ground for corruption, including that of Greek policy makers. As a result, few of the last Muslim landowners took advantage of the opportunity to change religion, and the last ones left Greece in the $1830 \mathrm{~s}^{40}$.

The Greek authorities hoped that the depopulated areas of the newly created state would be settled by Greeks coming from the Ottoman Empire, especially since the population losses during the War of Independence were extremely severe in this territory. Hence, the protocol of the London Conference provided that anyone who deemed himself a national of the new state could move to its territory (Art. 6). The main issue was first to allow Greeks to leave the areas affected by the uprising, which ultimately were not included within the borders of the Kingdom, and second to en-

36 Abstracts of Proceedings, FO 198/1/33 (Part VI); S. Katsikas, Millet legacies, p. 56-59.

37 R. Clogg, Historia Grecji nowożytnej, tłum. W. Gałąska, Warszawa 2006, p. 51; S. Katsikas, Millet legacies, p. 53-54.

38 Ž. Obradović, Minorities in the Balkans. 19th and 20th century, Belgrade 2015, p. 113.

39 R. Clogg, op. cit., p. 57.

40 S. Katsikas, Millet legacies, p. 53-54. 
courage those who could prove that they were facing repressions in connection with their activities in the 1820s. Such fears arose in connection with the anti-Greek riots in Constantinople, the islands, and Asia Minor. The Sublime Porte, however, did not want to allow the Greeks from the Ottoman Empire to emigrate freely, fearing negative consequences for the economy and the devastation of lands ${ }^{41}$. In later years, the process of the influx of Greeks from the lands under the Sultan's rule to the Kingdom was related to the events taking place in the Ottoman Empire after the Crimean War, the process of emigration from Thessaly, Epirus, and Macedonia to the Greek state was noted, which was associated primarily with the process of Circassian settlement. However, the immigrants did not stay in the Kingdom for a long time - they returned to their homes soon after the situation calmed down. The reason for these returns was their disappointment with the conditions in Greece and difficulties in finding new homes $^{42}$.

In the year 1834, the population of Greece was 651233 . Despite the pogroms and mass flights during the revolution, Muslims still lived on the territory, although these were very small groups, numbering a total of around 1000 people. Data from 1861 show that 385 inhabitants of Euboea were Muslim; other parts of mainland Greece were inhabited by 552 Muslims. They were mainly employees of the Sultan's remaining estates and people residing in Athens for professional reasons. The annexation of the Ionian Islands in 1864 did not increase the number of "Turks” in the country. These areas never fell within the borders of the Ottoman Empire, and Muslims did not settle there, thus, there could be no conversions to Islam ${ }^{43}$. At the same time, there was a rapid increase in the population of the Kingdom of Greece, which doubled between 1839 and 1879 , from 823733 to $1679470^{44}$.

In the first period of its functioning, the Greek state openly treated Muslims as foreigners, assuming that citizenship, nationality, and Orthodoxy were inseparable elements defining „Greekness”, the adoption of Greek citizenship most often amounted to the change of confession ${ }^{45}$. In Greece, the state successfully subordinated Church institutions to itself, which was additionally strengthened by the creation of an autocephalic Church, separate from the patriarchy in Constantinople. There were even opinions that the state and the Church were one entity ${ }^{46}$. This was reflected both in the first Greek constitution, passed during the revolution on 1 February 1822, as well as in the constitution of 15 March 1832. Only the constitutions of 1864 and 1911 intro-

41 Abstracts of Proceedings, FO 421/1/14 (Part VI).

42 Blunt to Mr. Longworth, Belgrade 03.07.1865, FO 78/1868/307-1311.

${ }^{43}$ K. Tsitselikis, op. cit., p. 34; S. Katsikas, Millet legacies, p. 47-48.

44 Н. Тодоров, ор. cit., p. 313.

45 H. Poulton, Changing notions of national identity among Muslims in Thrace and Macedonia: Turks, Pomaks and Roma, in: Muslim identity and the Balkan states, eds. H. Poulton, S. Taji-Farouki, London 1997, p. 82-83.

46 T. Czekalski, Kościół prawosławny w życiu politycznym nowożytnego państwa greckiego, in: Religijna mozaika Bałkanów, red. M. Walczak-Mikołajczakowa, Gniezno 2008, p. 145-147. 
duced guarantees regarding religious equality. On the other hand, as Stefanos Katsikas points out, state documents still did not treat this population as „Greek citizens”, but as „Muslims”, „Mohammedans”, ,Turks” or „Ottomans”, which was a synonym for Sultan's subjects. The clearest evidence of this position and its durability were the provisions of the treaties on the exchange of the population of 1923 , where the religious factor was the decisive one regarding resettlement ${ }^{47}$.

\section{ANNEXATION OF THESSALY}

Another exodus of Muslims from Greek lands was associated with the period of the Great Eastern Crisis and the annexation of Thessaly by the Hellenic Kingdom. From the beginning of the problems of the Ottoman Empire in 1875, Athenian authorities closely followed the developments in the Balkan Peninsula, and in 1876 they were pressured from Belgrade to join the war against the Sultan. Earlier the focus was on peaceful relations between Greeks and Muslims in Thessaly, which, however, did not stop the outbreak of Greek revolts in the second half of the 1870s. Such movements also took place in Epirus, Macedonia, and Crete, which met with veiled support from the Athenian government ${ }^{48}$. The entire population of Thessaly suffered from such activities, both Muslims and Christians. As early as mid-1878, it is said that Muslims fled from these territories (even the number of 10000 muhajirs is quoted) ${ }^{49}$. Athens supported the insurgent actions of the Greek population, which took on a broader dimension when the Ottoman army suffered one of the most severe defeats in the war with Russia - it lost the Pleven fortress in December 1877. Only on 2 February (18 January O.S.) 1878, Greek troops in the number of 25000 entered Thessaly, which, however, did not matter, as two weeks later the Ottoman-Russian truce was signed. Fearing that the Ottomans would move the forces involved so far in Bulgaria to the south, the authorities in Athens withdrew their troops. The resistance of the Greek community in Epirus continued. The peace in San Stefano concluded on 3 March (22 February O.S.) completely ignored Greek matters and served the pursuit of Bulgarian and Russian aspirations in the region, so the questioning of its provisions and transferring the burden of decision to the Berlin Congress met with new hopes of Greeks. Western powers told Athens that if they remained neutral to the events unfolding in the Balkans and tried to contain revolutionary movements in Thessaly, they would receive terri-

47 S. Katsikas, Millet legacies, p. 50-52; H. Poulton, Islam, ethnicity and state in the contemporary Balkans, in: Muslim identity, p. 19.

48 Earl Granville to Mr. Corbett, Foreign Office, 06.04.1881, FO 476/29/40-41; Balkanski ugovorni odnosi 1876-1996. Dvostrani i višestrani međunarodni ugovori i drugi diplomatski akti o državnim granicama, političkoj $i$ vojnoj saradnji, verskim i etničkim manjinama, vol. 1, ed. M. Stojković, Beograd 1998, p. 48-57.

49 S. Bandžović, op. cit., p. 123-124; N. Immig, The „New” Muslim minorities, p. 513-514. 
torial acquisitions once the situation had calmed down ${ }^{50}$. Indeed, the article 24 of the Treaty of Berlin provided for a change of the Greek-Turkish border under the mediation of powers ${ }^{51}$.

Negotiations with the participation of representatives of the Sublime Porte, Athens, and the signatories of the Treaty of Berlin began in 1880. It was emphasized that when delineating the new Greek-Turkish border, the key factor was the distribution of the Greek and Muslim population, so that too many Muslims should fall under the rule of Hellenes. They feared that the population would be quite dissatisfied with the decision, and in the case of a large group it could be lead to destabilization of the region and a Muslim revolt against the authorities in Athens ${ }^{52}$. It was emphasized that it would be particularly difficult to hand over Larisa to the Greeks, in which threequarters of the population were Muslims, and the city was surrounded by „Turkish” villages $^{53}$. There were similar doubts in the case of Arta, where Muslims also predominated. Not handing over the areas of Thessaly (which was inhabited by Greeks and Turks) was considered, and handing over Epirus instead, where Albanians lived next to Greeks ${ }^{54}$. The problem was the activity of the League of Prizren, which had a force of 20000 people as a result, the entry of the Greeks into the lands inhabited by the Albanian population could be even more troublesome and cause greater unrest than the seizure of Thessaly ${ }^{55}$. Just as the Christians in Thessaly declared that they did not want to live under Ottoman rule, which was tantamount to the constant fear of Muslim aggression, Albanians threatened not to give up their lands without a fight. After the transfer of Podgorica and Ulcinj to Montenegro and Sanjak of Nish to Serbia, and then the expulsion of Albanians from these territories, these people, represented by the League of Prizren, emphasized that they would not accept further territorial concessions to Christian countries, including the loss of Epirus to Greece ${ }^{56}$. There were also demands from the authorities in Athens that they should receive compensation in the

50 Analysis by Lord Tenterden of the Correspondence Relating to the Greek Frontier, FO 476/29/3-6.

51 Traktat berliński (13.07.1878), in: Historia Bułgarii 1870-1915. Materiaty źródłowe z komentarzami, t. 1, eds. J. Rubacha, A. Malinowski, A. Giza, Warszawa 2006, p. 45; J. Bonarek et al., op. cit., p. 505-507.

52 Lord Odo Russel to Earl Granville, Berlin 16.06.1880, FO 476/28/5-6 (Correspondence respecting the Conference at Berlin on the Rectification of Greek Frontiers); Memorandum by Mr. Currie on the Greek Frontier Question, 04.04.1880, FO 476/28/2-3; Sir H. Elliot to Earl Granville, Vienna 12.02.1881, FO 476/28/56-57 (Further Correspondence Respecting the Affairs of Greece, February 1881).

${ }_{53} \mathrm{Mr}$ Goschen to Earl Granville, Berlin 27.07.1880, FO 476/28/9-10 (Annexes to Memorandum by Mr. Currie on the Greek Frontier Question).

54 Sir L. Simmons to Lord Tenterden, 15.07.1880, FO 476/28/10-14 (Annexes to Memorandum by Mr. Currie on the Greek Frontier Question).

55 Consul St. John to Earl Granville, Ragusa 26.02.1881, FO 476/28/17 (Further Correspondence Respecting the Affairs of Greece, March 1881).

56 Consul Reade to Earl Granville, Corfu 8.03.1881, FO 476/28/41-42 (Further Correspondence Respecting the Affairs of Greece, March 1881); Negotiations for the rectification of the Greek frontier from the Treaty of Berlin of 1878 to the Convection, signed at Constantinople May 24, 1881, FO 881/5254/23. 
form of Crete, for which there was no doubt of predomination of the Hellenic community there ${ }^{57}$. It turned out to be impossible to precisely delineate the boundaries according to the religious and ethnic key. The British in January 1881 carried out a site visit in the area of Paramythia and Margariti. They emphasized that the population there was mixed: Greeks lived mainly in the plains, and Muslims, including Albanianspeakers, in the hills. As a result, these regions remained under the Ottoman rule. The case was the same with Preveza ${ }^{58}$.

The position of the Ottoman authorities was initially intransigent, which led to the mobilization announced by the Greeks and the threat of another war. The Sublime Porte reminded what Serbia and Montenegro did with Muslims in the areas annexed in 1878. It was feared that death and exile would also await Muslims in the areas transferred to Greece ${ }^{59}$. The handing over of such a large city [Larisa] by the caliph, an Islamic leader, under the authority of the Christian king will shake his authority as the ruler of the empire and all Muslims - Edward Goschen, a British diplomat, expressed his concerns for the stability of the Ottoman state ${ }^{60}$. It was argued that the case of Thessaly could prove destructive to the sultan's position and lead to a new crisis, and muhajirs from the Balkans in Asia Minor spoke with less and less respect of Abdulhamid II as a ruler who is unable to adequately protect his subjects and gives up Muslim lands without firing a shot. The Sublime Porte, however, was in a hopeless situation. To break negotiations with the Greeks and refuse to hand over Thessaly would be tantamount to a war with the Kingdom or a Greek uprising. Such a situation could be used by other countries in the region, Russia, as well as revolutionaries active throughout the Balkans. The Ottoman Empire, weakened after years of conflicts and rebellions, could not risk prolonging the Great Eastern Crisis ${ }^{61}$. However, it should be emphasized that in Thessaly and Epirus, in February 1881, the number of Ottoman garrisons was increased from 43000 to 50 000, and in addition, 3 000-4 000 irregular bashi-bazouk formations were mobilised. In other words, the Sublime Porte did not entirely rule out a war scenario ${ }^{62}$.

Already during the talks there were no illusions that Greece would have to promise to respect the religious and property rights of ,Turks”. It was emphasized, however, that these rights had to be enjoyed by the Muslims, regardless of whether they

57 Ibidem, FO 881/5254/14.

58 Memorandum by General Sir L. Simmons, G.C.B., FO 476/28/91-93 (Correspondence Respecting the Affairs of Greece, January 1881); Sir L. Simmons to Lord Tenterden, 15.07.1880, FO 476/28/10-14 (Annexes to Memorandum by Mr. Currie on the Greek Frontier Question).

59 Ibidem.

60 Mr Goschen to Earl Granville, Berlin 27.07.1880, FO 476/28/9-10 (Annexes to Memorandum by Mr. Currie on the Greek Frontier Question).

61 Sir L. Simmons to Lord Tenterden, 15.07.1880, FO 476/28/10-14 (Annexes to Memorandum by Mr. Currie on the Greek Frontier Question).

62 Consul St. John to Earl Granville, Ragusa 24.02.1881, FO 476/28/16 (Further Correspondence Respecting the Affairs of Greece, March 1881). 
would stay in Greece or emigrate. The idea was to guarantee them the possibility of selling, renting, or even leaving empty property. The representatives of the powers also introduced the condition that Muslims could not be isolated from public functions, and that both officials and parliament deputies should be selected from among them ${ }^{63}$. Edward Goschen argued, however, that Greece should not be burdened with such restrictions as in the case of Bulgaria or Serbia, in contrast to which it was an old state with a stabilized legal and political system. The British diplomat was convinced that there was no need to introduce autonomy for Thessaly within the Kingdom, but only to secure Muslim property rights and oblige the Greek administration to respect Ottoman property deeds ${ }^{64}$. Then, in May 1881, observing the fate of the Muslims in the province, Goschen changed his mind and emphasized the need for completely independent Islamic administrative and judicial institutions, following the example of those in Eastern Rumelia ${ }^{65}$.

Originally, it was planned to transfer to Greece the area of Thessaly, Arta, and Epirus inhabited by 500 000-600 000 people, of which 71 000-85 000 were Muslims. The biggest aspirations of the authorities in Athens was controlling the territories marked in green and white in the above illustration ${ }^{66}$. Until the last moment, the Sublime Porte protested against handing over of Larisa due to the Muslim majority in the city, but also the existence of numerous religious buildings there and concentration of Muslim property. The Muslims themselves were also against it. The people protested in Ioannina, Arta, Preveza, and Margariti ${ }^{67}$.

The pressure from the great powers on the Sublime Porte proved successful in the end. After long negotiations, on 2 July 1881, the Ottoman-Greek Convention of Constantinople was signed. In the first two articles, the document described the new frontiers. In the above illustration, the area finally joined to the domain of the Hellenic Kingdom is marked in green. Greece undertook to respect the rights to life, property, dignity, worship, and customs of all inhabitants of the assigned territory on an equal basis with other citizens of the state. In a separate article, the authorities in Athens guaranteed property rights based on Ottoman ownership deeds and the preservation of waqfas. The Ottoman state property was to be transferred under the control of the Greek government through a specially appointed Ottoman-Greek commission, which was to determine the amount of compensation due to the Sublime Porte with-

63 Memorandum by Mr. Currie on the Greek Frontier Question, 04.04.1880, FO 476/28/5.

64 Mr. Goschen to Earl Granville, Constantinople 19.04.1881, FO 476/29/97-98 (Further Correspondence Respecting the Affairs of Greece, April 1881).

65 Mr. Goschen to Earl Granville, Constantinople 13.05.1881, FO 476/29/63-64 (Further Correspondence Respecting the Affairs of Greece, April 1881).

66 Sir L. Simmons to Lord Tenterden, 15.07.1880, FO 476/28/10-14 (Annexes to Memorandum by Mr. Currie on the Greek Frontier Question).

${ }^{67}$ Alternative Lines of Frontier which may be taken into consideration by an International Arbitration Commission by Major J.C. Ardagh, C.B., R.E., D.A.Q.M.G., 15.01.1881, FO 476/28/9, 12-13 (Further Correspondence Respecting the Affairs of Greece, February 1881). 


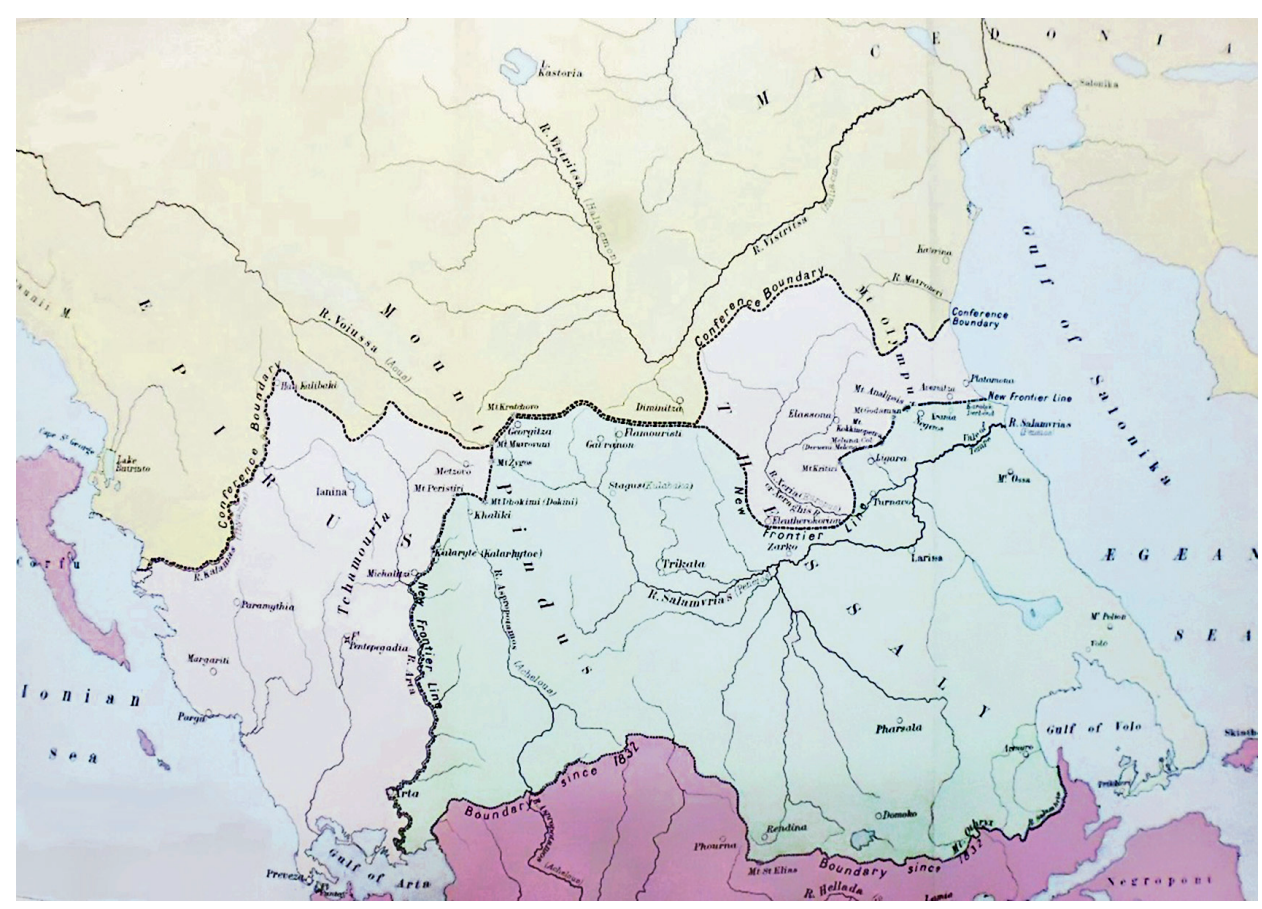

Map 1: The division of Thessaly between Greece and the Ottoman Empire in 1881 [Source: FO 476/29]

in two years. At the same time, its task was to supervise the observance of the property rights of Muslims in the Kingdom. The convention strictly prohibited carrying out of any expropriations, even with compensation or by law. Forcing landowners to sell their lands or parcel them out was also ruled out. It was clearly emphasized that any law regulating agricultural relations had to apply to all citizens along the same principles. Shepherds and farmers who leased pastures or fields in Thessaly were guaranteed the right to continue their economic activity. In a separate article, Muslims were promised religious freedom and Islamic religious institutions were to preserve their property. The state undertook not to interfere in filling the positions of leaders of the Muslim community and to maintain the judiciary within the Sharia law. The authorities in Athens also ensured that they would not in any way harm the Muslims of Thessaly. From the point of view of the position of the Islamic community, one of the last articles of the document was crucial. It indicated that every resident of Thessaly had three years to decide whether to accept Greek citizenship or remain subject to the Ottoman Sultan, which was tantamount to leaving the country. At the same time, emigrants were guaranteed the full rights described in the treaty and Muslims were exempt from military service for a period of three years. The convention also prohibited the imposition of new taxes on the population of the ceded territories, reflecting concerns that it could be a tool to get rid of the Muslims of Thessaly. Issues related to the 
implementation and observance of the Convention were under the supervision of the signatories to the Treaty of Berlin ${ }^{68}$.

The Ottoman authorities had a number of objections to the final shape of the convention, resulting largely from the first experiences in the protection of Muslim rights in Serbia and Bulgaria. They demanded that the document should contain guarantees from the central and local Greek authorities regarding the protection of mosques, madrasas, Muslim schools, and other Islamic buildings in Thessaly. A provision was proposed for the transfer of waqfas to the management of hodjas, mosques to imams and Muslim cemeteries to Islamic communes. The Sublime Porte also counted on additional protection of the competence of courts subordinate to Shaykh al-Isläm and specifying the extent of their jurisdiction. Another important issue was the introduction of special guarantees related to the handling of property left in Greece by the Muslim emigrants during their stay abroad. There was also insistence on the extension of the transitional period for those who chose not to acquire Greek citizenship to ten years ${ }^{69}$.

As a result, the area of Thessaly and Arta, inhabited by 45300 Muslims, concentrated in Larisa, Trikala, Tyrnavos, Almyro, Karditsa, Volos, and their surroundings, were incorporated into the Kingdom of Hellenes. This region was dominated by Greeks (292 000), also a Jewish community (6 000) lived there. Larisa itself was at that time inhabited by 24000 people, of whom 13000 were Muslims, 8000 Greeks, and 3000 Sephardic Jews. The oriental character of Thessalian cities was also emphasized, for example, the large number of mosques in Larisa (27). There were 3000 Muslims living in Trikala, in Karditsa 2 800, and in Volos $1400^{70}$.

The very handover of these areas under Greek rule was peaceful. It took place under the supervision of a commission composed of representatives of the powers and the Ottoman Empire. There was a solemn, month-long tour of the king and prime minister around the new province, during which the ruler first met with representatives of the Muslim community. The authorities in Athens made a number of gestures encouraging Muslims to stay in Thessaly, and there were opinions that integration should be aimed at. The competition for the votes of the large Islamic community during the supplementary elections to the parliament was also important. Moreover, two Muslims became deputies; they were allowed to swear by the Quran, not the Bible, as in the case of Greek deputies. However, it should be remembered that the presence

68 Apendix: Convention, FO 476/29/31-33 (Analysis by Lord Tenterden of the Correspondence Relating to the Greek Frontier).

${ }^{69}$ First Annex to the General Protocle. Articles presented by the Ottoman Phenipontiaries at the First Conference, 476/29/21-22 (despatch from Mr. Goschen forwarding the Convection for the settlement of the frontier between Greece and Turkey, signed at Constantinople, 24.05.1881).

70 Alternative Lines of Frontier which may be taken into consideration by an International Arbitration Commission by Major J.C. Ardagh, C.B., R.E., D.A.Q.M.G., 15.01.1881, FO 476/28/10 (Further Correspondence Respecting the Affairs of Greece, February 1881); S. Bandžović, op. cit., p. 187 188; K. Tsitselikis, op. cit., p. 34-35. 
of the Muslims in the Greek parliament was basically irrelevant: They did not participate in debates, even on a matter as important to the people they represented as the issue of potential agrarian reform in Thessaly ${ }^{71}$.

Muslims from Thessaly were dissatisfied with the fact that the region would come under Greek rule, but there were also voices that they appreciated the content and principles of the Constantinople Convention. Some hoped that Greeks, as promised, would allow them to live as they did before 1881 . This is illustrated by the question of the Larisa beys to the British Vice-Consul John Augustus Longworth, who wanted to know if, in the light of Article 3, which guaranteed the protection of Muslim customs, they would still be able to have harems. Longworth assured them that there would be no objection to harems as long as there were no slaves there ${ }^{72}$. After the announcement of the content of the convention, rumours appeared about the outbreak of Muslim riots in the Arta area, but the information was quickly denied ${ }^{73}$. Muslim beys from the Karditsa region have announced that they were not planning on leaving, but would submit to the authorities and offered help in introducing the new administration ${ }^{74}$. British Consul in Thessaloniki, Charles Blunt, quotes the story of a local bey who also owned land in Thessaly. The Muslim was preparing to sell his property even before the Greek takeover of the province was announced, from which Blunt managed to dissuade him. In October 1881, the Thessaloniki bey recognized that the rights of Muslims in Thessaly were respected and at this stage refrained from selling the lands ${ }^{75}$. Beys' position was crucial in the decision of other members of the community concerning leaving as community leaders, they had a great influence on other Muslims $^{76}$. The deadline given to Muslims to acquire Greek citizenship was also important in this matter, and the refusal to do so and remaining the sultan's subject was tantamount to the decision of leaving. The Constantinople Convention indicated that the Muslims should make their decisions on the issue by 1884 , and then this period was extended to $1889^{77}$.

However, it cannot be denied that the reaction to the announcement of the decisions contained in the Constantinople Convection were departures: Many Muslims decided that they would not be able to live under Christian rule and feared reprisals. Greeks

71 N. Immig, The „New” Muslim minorities, p. 514-515, 517.

72 Vice-Consul Longworth to Mr. Plunkett, Larissa 15.06.1881, FO 476/29/53 (Correspondence respecting the Affairs of Greece, June 1881).

73 Earl Granville to Major-General Sir E. Hamley, Foreign Office 20.07.1881, FO 476/29/18 (Respecting the Affairs of Greece, July 1881); Major-General Sir E. Hamley to Earl Granville, Therapia 21.07.1881, FO 476/29/19 (Respecting the Affairs of Greece, July 1881).

74 Consul-General Blunt to Earl Granville, Salonica 10.07.1881, FO 476/29/19-20 (Respecting the Affairs of Greece, July 1881).

75 Consul-General Blunt to Earl Granville, Salonica 31.10.1881, FO 476/29/7-8 (Further Correspondence Respecting the Affairs of Greece, November 1881).

76 Vice-Consul Longworth to Earl of Dufferin, Larissa 26.10.1881, FO 476/29/8 (Further Correspondence Respecting the Affairs of Greece, November 1881).

77 N. Immig, The ,New” Muslim minorities, p. 515. 
emphasized that when they noticed that the introduction of Greek administration in Thessaly was proceeding peacefully, many decided to return to their homes ${ }^{78}$. This could give a false impression, as many people returned only to quickly sell their property and leave again. Muslim agitators who called for people to leave „the land of the giaours" had their share in the emigration process and settling in the city of Hamidich, which was founded at that time, as a new Muslim centre on the border with Arta. This was done with the assistance of representatives of the Sublime Porte, which was getting ready to accept new waves of emigrants ${ }^{79}$. British diplomats explained the exodus from Thessaly with the „nomadic mentality” of „Turks”, which was manifested in the fact that although they had lived in these areas for centuries, they had felt alienated and expressed dislike of their Greek neighbours ${ }^{80}$. The group which stood out from those that definitely decided to leave Greece were Ottoman military and officials ${ }^{81}$.

The local authorities and the Greek army, who were in diverse ways forcing Muslims to leave, were also blamed for the emigration. Contrary to Greek assurances and arbitration, there were acts aimed against this community, including devastation of Islamic cemeteries, and building an atmosphere of aversion or indirect pressure on leaving. In Volo, drunken residents of the nearby village of Makrinitsa attacked the local mosque and „Turkish” houses, which was not treated as a simple act of vandalism. The perpetrators emphasized that it was retaliation for the destruction of the churches in their town by Ottoman soldiers in January $1881^{82}$.

As early as December 1881, it was reported that out of 40000 Muslims from Thessaly, 3000 had decided to sell the property and left since July. Half of them were employees of the Ottoman public sector who had lost their jobs. Most Muslims of Larisa, Tricali, Armyro, and Volo left. They departed by ships from ports to Smyrna. Returns from Anatolia were rare at that time there were reports of several families who, disappointed with the conditions in Asia Minor, decided to return to Thessaly ${ }^{83}$. However, these numbers could be larger, as shown by the data from Larisa, which had 24000 inhabitants before 1881, and in August that year it was reported that this number had dropped to 14 000. The British vice-consul in Larisa, John Augustus Longworth, emphasized that the process of emigration of Muslims from the city was still ongoing and Turks and Albanians with damaged reputation were preparing for

78 Consul Onofrio to Acting Consul Woodley, Santa Maura 17.07.1881, FO 476/29/19 (Respecting the Affairs of Greece, July 1881).

79 Consul Onofrio to Consul Reade, Santa Maura 05.11.1881, FO 476/29/9 (Further Correspondence Respecting the Affairs of Greece, November 1881).

80 Major Ardagh to Earl Granville, In Camp, near Malakasi, 25.08.1881, FO 476/29/9-10 (Further Correspondence Respecting the Affairs of Greece, September 1881).

81 Earl Granville to Mr. Goschen, Constantinople 10.05.1881, FO 476/29/41 (Further Correspondence Respecting the Affairs of Greece, May 1881).

82 Vice-Consul Longworth to Earl of Dufferin, Volo 3.12.1881, FO 476/29/27 (Further Correspondence Respecting the Affairs of Greece, November 1881).

83 Ibidem. 
departure $^{84}$. Another wave of migration occurred in 1884, when exemption from military service was lifted ${ }^{85}$ and which was the year of the original date for declaration of Greek citizenship. Some commentators argued that after a three-year transition period, Muslims in Thessaly will become fully subject to Greek law and constitution, referring to the adoption of Greek citizenship by those who remained ${ }^{86}$. The next incentive for migration was the Thirty Days' War in 1897, when the Greek defeat in the clash with the Ottoman Empire led to an increase in anti-Islamic sentiment in the country. In 1890, there were 13163 Muslims in the Kingdom of Greece (out of 2,2 million of the country's total population), in 19076 301, of which 2785 in Thessaly, and 3516 in other parts of Greece (per 2632000 ), and in $19112900^{87}$. Thus, departures took place gradually. It is indicated that for example the Muslim community in Trikala ceased to exist at the end of the 19th century ${ }^{88}$.

The challenge for the state was to populate Thessaly, especially in the face of the growing problem of mass emigration to the USA. In the years 1890-1914, 350000 people emigrated overseas, that is every sixth inhabitant of Greece, and over $60 \%$ of this group did not return to the country ${ }^{89}$. As a result, at the turn of the century, the increase in the population of Greece $(0,7 \%$ per year) was comparatively lower than in other Balkan countries: Serbia $(1,63 \%)$, Bulgaria $(1,58 \%)$, or Bosnia and Herzegovina controlled by Austria-Hungary $(1,58 \%)^{90}$.

Officially, the stance of the government in Athens towards departures was negative. This attitude can be explained in various ways: the fear of the Greek elites of the negative economic effects of the mass exodus of Muslims on the countryside or the demonstrative implementation of the conditions for the transfer of Thessaly to the Greek state to the approval of the great powers ${ }^{91}$. It was also emphasized that the Greek authorities' respect for the rights of Muslims would have an impact on the attitude of the Ottoman Empire towards the Greeks in Macedonia, Thrace, and Epirus ${ }^{92}$. It is also

84 Vice-Consul Longworth to Earl of Dufferin, Larissa 26.08.1881, FO 476/29/11-12 (Further Correspondence Respecting the Affairs of Greece, September 1881).

85 Therefore, during the negotiations, the Sublime Porte insisted that the community should be completely released from this obligation towards the state. Mr. Goschen to Earl Granville, Constantinople 13.05.1881, FO 476/29/59-61 (Further Correspondence Respecting the Affairs of Greece, April 1881).

86 Vice-Consul Longworth to Earl of Dufferin, Larissa 26.10.1881, FO 476/29/8 (Further Correspondence Respecting the Affairs of Greece, November 1881).

87 K. Tsitselikis, op. cit., p. 36; S. Bandžović, Deosmanizacija Balkana, p. 187-188; N. Clayer, X. Bougarel, Les musulmans de l'Europe du Sud-Est: des empires aux états balkaniques, Paris 2013, p. 72; S. Drakulic, Anti-Turkish Obsession and the Exodus of Balkan Muslims, „Patterns of Prejudice” 2009, vol. 43, no. 3/4, p. 247; J. McCarthy, Muslim in Ottoman Europe: population from 1880 to 1912 , „Nationalities Papers” 2000, vol. 28, no. 1, p. 38.

88 J. Bonarek et al., op. cit., p. 522.

89 Ibidem, p. 516-517.

90 М. Паларе, op. cit., p. 39.

91 N. Immig, The „New” Muslim minorities, p. 515.

92 Consul-General Blunt to Earl Granville, Salonica 31.10.1881, FO 476/29/7-8 (Further Correspondence Respecting the Affairs of Greece, November 1881). 
significant in this context that the Orthodox Church in the Kingdom of Greece did not attempt to convert this population ${ }^{93}$.

The guarantees granted to Muslims in Thessaly under the Constantinople Convention of 2 July 1881 obligated the authorities in Athens to secure the life, dignity, property, and religious autonomy of Muslims and to recognize the Sharia judiciary on the territory of the Kingdom of Greece ${ }^{94}$. In the capital of each district, a mufti was appointed to deal with weddings, divorces, matters of inheritance, oversee mosques, waqfas, denominational schools, and charity within the zakat. One muftlik was to cover a community of 40000 Muslims, which did not correspond to the actual number of Muslims in the country, especially in view of the increased emigration. Muftis were established only in Thessaly, because apart from the areas newly attached to Greece, there were no compact Muslim communities in the country. In 1882, there were four muftliks: in Larisa, Farsala, Trikali, and Volo; in 1910, another one was created in Karditsa. The mufti was elected by members of the Islamic community, but was under the control of the Greek government and treated like a government official. In addition to muftis, in 1889, Muslim councils were established to administer mosques, schools, and waqfas at the local level ${ }^{95}$.

In fact, the situation of minorities was not as rosy as the Greek authorities presented it to the powers. Although, the political parties were aware that they should compete for Muslim votes in parliamentary elections, the political rights of the latter were restricted. In order to prevent significant representation of Muslims in the Greek parliament, many of the new Muslim subjects of the King of the Hellenes were not entered on the election lists in December 1881. This was explained by the fact that they did not have the status of Greek citizens, which was related to the three-year transition period ${ }^{96}$. There were also incidents related to the closure of Muslims in their own homes by the Greek population so that they could not participate in voting. Such cases were reported, for example, in Domokos or Farsala ${ }^{97}$. The political role of Muslims in the region was gradually limited. The Muslim mayor (muhtar) of Larrisa, Halil Bey, remained in his position after the annexation of Thessaly, but in August 1882,

93 The careful attitude of the hierarchy to this issue can be illustrated by the situation which took place in 1891. The minor son of the Mufti of Sofia in Bulgaria, who was studying in Adrianople, decided to flee to the Greek capital, where he declared his will to be baptized. The Metropolitan of Athens, Germanos acted very cautiously. He said that the boy would be able to convert only after the age of eighteen, and before that he would have to study Christianity. „Балканска зора” 1891, vol. 2, no. 486 (08.11.1891), p. 3.

94 There were doubts as to whether the Sharia judiciary could function in the territory of the Kingdom of Greece, as the constitution of 1864 forbade the existence of non-state courts and stipulated that every judge had to be apointed by the king. No kadi or naib was apointed by the head of state to office in Greece.

95 K. Tsitselikis, op. cit., p. 35; S. Katsikas, Millet legacies, p. 54-56.

96 Mr. Ford to Earl Granville, Athens 15.11.1881, FO 476/29/18 (Further Correspondence Respecting the Affairs of Greece, November 1881); Consul-General Blunt to Earl Granville, Salonica 08.11.1881, FO 476/29/18 (Further Correspondence Respecting the Affairs of Greece, November 1881).

97 S. Katsikas, Millet legacies, p. 61. 
he was dismissed, retaining the unofficial function of the leader of the Muslim inhabitants of the city. The Athenian newspaper „Paliggenisia” reported, that the mayor's loss of office was related to suspicious contacts between bey and the authorities in Constantinople, but also to him sowing the seeds of ferment among the Ottoman fellow citizens. Muslims were openly spoken of as foreigners who contributed to poisoning the atmosphere in Thessaly ${ }^{98}$.

The key influence on the emigration of Muslims was caused by the questioning of their property rights by Greeks. The most convenient way to strip Muslims of their property was by not recognizing the authenticity of Ottoman property deeds. The Greek authorities also used the tax system to act against Muslim landowners and make it unprofitable for them to run their farms. This was done against the Constantinople Convention, in which the authorities in Athens undertook to recognize Ottoman deeds of ownership (tapi) and not to levy new taxes ${ }^{99}$. Just like after the War of Independence, there were many speculators who wanted to use the situation of Muslims to increase their wealth ${ }^{100}$. Some Greek peasants from Thessaly decided to boycott the regulation of the leases due to beys, although these actions were also targeted against Christian landowners. Greek peasants emphasized that they lived in a free Greek state and were no longer subject to their old masters ${ }^{101}$. The land reform sought by the Greek peasants was not introduced in Thessaly. Peasants still owned no land and worked on large farms belonging to wealthy, mostly diaspora-born Greeks who bought the lands from beys ${ }^{102}$. Before 1881 , Thessaly was one of the areas with the most chiftliks in Turkey-in-Europe, and after joining this area to Greece, there were still many such farms left there ${ }^{103}$. The Greeks also looked greedily at the waqfs, which were to function under the Constantinople Convention according to the same principles as before 1881. This was, however, not observed. Properties of this type were in many cases considered to be the property of the sultan, and thus they were nationalized. As a result, they were taken over by the state treasury for compensation paid to the Sublime Porte, and the Muslim communities in Thessaly were left without financial support ${ }^{104}$.

98 N. Immig, The „New” Muslim minorities, p. 519.

99 Mr. Goschen to Earl Granville, Constantinople 13.05.1881, FO 476/29/63-64 (Further Correspondence Respecting the Affairs of Greece, April 1881).

$100 \mathrm{Mr}$. Goschen to Earl Granville, Constantinople 10.05.1881, FO 476/29/44 (Further Correspondence Respecting the Affairs of Greece, April 1881).

101 Major Ardagh to Earl Granville, In Camp, near Malakasi, 25.08.1881, FO 476/29/9-10 (Further Correspondence Respecting the Affairs of Greece, September 1881).

102 J. Bonarek et al., op. cit., p. 516.

103 M. Dymarski, Konflikty na Bałkanach w okresie ksztattowania się państw narodowych w XIX i na początku XX wieku, Wrocław 2010, p. 49.

${ }^{104} \mathrm{Mr}$. Goschen to Earl Granville, Constantinople 13.05.1881,476/29/63-64(FurtherCorrespondence Respecting the Affairs of Greece, April 1881). 


\section{THE CASE OF CRETE}

Muslim emigration during this period also took place in other Greek lands, where the position of the Hellenes was gradually strengthening. Crete, from which Muslims left, is an unusual case here despite the fact that the island remained within the borders of the Ottoman state until the Balkan Wars. After the Berlin Congress, under the Aleppo Convention of 1878, extensive autonomy of the island was introduced, which guaranteed a separate administration with a Greek governor appointed every five years, as well as the local parliament and gendarmerie. In 1889, the Sublime Porte, however, suspended this status on the pretext that it became a source of conflicts between Cretan politicians. The reaction was an uprising of the Orthodox population, which the Ottoman troops managed to suppress. Cretan Greeks took up arms again in 1897, and during the fighting brutal pogroms against Muslims took place. The powers forced the Sublime Porte to re-grant the island autonomy, which in fact gave it the status of a separate state, loosely related to the Ottoman Empire with a system that assumed a balance between Christians and Muslims ${ }^{105}$. During this period, Eleftherios Venizelos, as the Minister of Justice of Crete, tried to implement the principle of equality of rights between representatives of two religions: One-third of the seats in the parliament were reserved for Muslims, the rest was open for Greeks. Muslims were guaranteed the rights to keep all waqfas (which was one of the main sources of conflict between the Christian and Muslim inhabitants of the island), their own education and the Sharia judiciary connected with Shaykh al-Islām in Constantinople, and to secure seats in the provincial administration. Greek was recognized as an official language under the constitution of 1899 , which was not controversial as the majority of Muslims living on the island were Greek-speaking. It was only with the introduction of the new constitution of 1907 that Orthodoxy was recognized as the dominant religion. A year later, the Cretan parliament announced that the constitution of the Kingdom of Greece was also binding on the island, but this was not recognized either by the powers or by Athens. Crete was incorporated into the Hellenic state in 1913, although the special status of Muslims was retained until the population exchange in $1923^{106}$.

The situation on the island, related to the regular uprisings and pogroms against the Muslim population and the increasing position of the Greeks, had major influence on both the internal and external migration process. Initially, people moved from the countryside to cities, mainly to Chania, Iraklion, and Rethymno, where greater security was guaranteed to the Muslims, especially when the Ottoman troops stationed there until 1897. However, when with the introduction of autonomy the troops were withdrawn, Muslim population started to permanently leave Crete on an increasing scale.

105 U.Z. Peçe, An island unmixed: European military intervention and the displacement of Crete's Muslims, 1896-1908, „Middle Eastern Studies”, 2018, vol. 54 no. 4, p. 575-583.

106 K. Tsitselikis, op. cit., p. 37. 
In the early $1830 \mathrm{~s}$, it is estimated that in one of the key Cretan cities, Iraklion, there were 30000 Greeks and 30000 Muslims $^{107}$. At the turn of the 19th and 20th centuries, there was a clear decline in the Muslim population numbers, which was the result of departures, especially from major urban centres. In 1911, there were only 500 Muslims in Iraklion, and 1000 in Rethymno. In these centres, which in the 19th century were dominated by Muslims, at that time Greeks began to outnumber. Even the local Bektashi, who had traditionally maintained good relations with Christians, decided to leave the island. The total number of Muslims who left Crete between the outbreak of the Greek War of Independence and the Balkan wars is estimated at 130 000. Many of them headed for Ottoman-controlled Rhodes and Kos. In 1881, 203000 Christians and 72000 Muslims (26\%) lived on the island. The percentage of Muslims did not change until 1896, and their number increased to 80000 . Over the next four years, this number dropped to $33500(1 \%)$, and in 1911 to 28000 . This shows how crucial the uprising of 1897 and the establishment of the Greek government in Crete was for decisions on departures ${ }^{108}$.

\section{CONCLUSION}

Traditional Greek historiography is no different in its interpretations of the exodus of Muslims in the 19th century from that of other countries in the region: The „Turks" did not leave their homes, but re-emigrated to their former homeland, i.e. Asia, driven by religious fanaticism and the lack of acceptance of changes in the world around them $^{109}$. In the context of the period after 1881, the key influence was also exerted by agitators sent by the Ottoman Empire calling for the faithful people to leave the ,state of giaours" ${ }^{110}$. On the other hand, the belief that the departures of Muslims from Greece were a manifestation of the planned policy of repression carried out by the government in Athens became consolidated over time in general historiography ${ }^{111}$. However, the process was more complex. There are clear differences between the policy of the Athens government after the War of Independence and the annexation of Thessaly. It was related to the international context. It was the Treaty of Berlin which introduced a number of regulations regarding the protection of Muslims in the Balkans. The period of the Greek Revolution and the following years was the time, as Justin McCarthy put it, of death and exile. As a result of the violence and coercion used by the Greeks with the final consent of the great powers and the Sublime Porte,

107 Abstracts of Proceedings, FO 198/1/39 (Part VI).

108 K. Tsitselikis, op. cit. p. 36-38; U.Z. Peçe, op. cit., p. 580, 584.

109 N. Immig, The „New” Muslim minorities, p. 513.

110 S. Katsikas, Millet legacies, p. 61.

111 Idem, European modernity and Islamic reformism among Muslims of the Balkans in the lateOttoman and post-Ottoman period (1830s-1945), „Journal of Muslim Minority Affairs” 2009, vol. 29, no. 4 , p. 539 . 
in the 1820 s and 1830 s, the Muslim community practically disappeared from the areas controlled by Greeks. After 1881, a key role in the gradual process of Muslim emigration from Greece was played by socio-economic factors, the inability of local Muslims to adapt to the changes which took place, and the lack of acceptance of the rule of the ,former rayah". Although there were direct repressions and discrimination, they were not of decisive importance and did not violate the standards prevalent in Europe at that time ${ }^{112}$. Conflicts between Greeks and Muslims were not only of ethnic, but also of social nature, as evidenced by the fact that in Thessaly to a similar extent Greek peasants were involved in disputes over the parcelling of large landed estates with Muslim beys and with Greek owners ${ }^{113}$. The reasons indicated (violence and discrimination as well as socio-economic factors) were intertwined, regardless of whether, as during the Greek Revolution and in the first half of the 19th century, there was no international protection of Muslim rights in Greece, or as after 1881 it did exist, however, the authorities were able to disregard it in some aspects.

The process of the exodus of Muslims from the Greek state can be divided into two phases, regardless of whether one has in mind the first half of the 19th century or the period after the annexation of Thessaly or the Crete case. First, there were escapes from pogroms for fear of life in the period of revolutionary turmoil or at the news that the area had come under Christian rule. After the situation became more stable, the decision to migrate was influenced by the changes in the political and social status and the difficult economic situation related to the forced role of second-class citizens ${ }^{114}$.

It must be remembered, however, that before 1821, in Continental Greece and in Peloponnese, there were no large Muslim communities in comparison with other regions of the Balkans. Muslims had already migrated in large numbers from Greek lands as a result of the Venetian-Turkish wars. Comparing the case of Greece with other Balkan countries, e.g. Bulgaria, proves that it was much easier to force Muslims to leave the areas where they did not constitute a cohesive community. This factor, as well as the beginning of the formation of statehood in the first half of the 19th century, when virtually no international rules for the protection of minorities had yet existed, made it possible to build ethnically homogeneous states ${ }^{115}$.

112 N. Immig, The „New” Muslim minorities, p. 516.

113 Mr. Ford to Earl Granville, Athens 28.11.1881, FO 476/29/1 (Further Correspondence Respecting the Affairs of Greece, December 1881).

114 N. Immig, The „New” Muslim minorities, p. 518-519.

115 See: K. Popek, Muslim emigration from the Balkan peninsula in the 19th century: a historical outline, „Zeszyty Naukowe UJ. Prace Historyczne” 2019, vol. 146, no. 3, p. 517-533; idem, “A Body Without a Head". The Elite of the Muslim minority in the Bulgarian lands at the turn of the 20th century, „Balcanica Posnaniensia. Acta et studia”, 2018, t. 25, p. 129-141; idem, Muhadzirowie. Uwagi na temat emigracji muzulmanów z ziem butgarskich na przełomie XIX i XX wieku, „Balcanica Posnaniensia. Acta et studia", 2016, t. 23, p. 47-69. 


\section{BIBLIOGRAPHY}

\section{Archival sources:}

Foreign Office Archives, Public Record Office, London (FO):

78 (Political and Other Departments: General Correspondence before 1906, Ottoman Empire); 198

(Southern Department and Foreign Office: Embassy and Consulates, Turkey, formerly Ottoman Empire: Miscellanea); 352 (Stratford Canning Papers); 476 (Confidential Print: Greece); 881 (Confidential Print).

\section{Print sources:}

Balkanski ugovorni odnosi 1876-1996. Dvostrani i višestrani međunarodni ugovori i drugi diplomatski akti o državnim granicama, političkoj i vojnoj saradnji, verskim i etničkim manjinama, ed. M. Stojković, Beograd 1998, vol. 1.

Historia Bułgarii 1870-1915. Materiały źródtowe z komentarzami, red. J. Rubacha, A. Malinowski, A. Giza, Warszawa 2006, vol. 1.

Makrijanis J., Topornym piórem. Pamiętniki z powstania greckiego i pierwszych lat wolności, ed. M. Borowska, Warszawa 2010.

The Foundation of the modern Greek state. Major treaties and conventions (1830-1947), ed. Ph. Constantopoulou, Athens 1999.

\section{Press:}

[„Balkanska zora” (Plovdiv), 1891 [„„Балканска зора” (Пловдив), 1891].

\section{Publications:}

Bandžović S., Bošnjaci i deosmanizacija Balkana: muhadžirski pokreti i pribježišta ,, sultanovih musafira” (1683.-1875.), Sarajevo 2013.

Bojarski A., Powstanie Greków w latach 1821-1829, Warszawa 2011.

Bonarek J., Czekalski T., Sprawski S., Turlej S., Historia Grecji, Kraków 2005.

Christopoulos D., Islam and state religion in Greece: from the formation of the „Greek-Orthodox Genos” to the era of migration, in: Strengthening religious tolerance for a secure civil society in Albania and the southern Balkans, eds. J. Pettifer, M. Nazarko, Amsterdam-Berlin-Oxford-Tokyo-Washington 2007, p. 66-72.

Clayer N., Bougarel X., Les musulmans de l'Europe du Sud-Est: des empires aux états balkaniques, Paris 2013.

Clogg R., Historia Grecji nowożytnej, transl. W. Gałąska, Warszawa 2006.

Crossing the Aegean: the consequences of the 1923 Greek-Turkish population exchange (studies in forced migration), Providence 2003.

Czekalski T., Kościót prawosławny w życiu politycznym nowożytnego państwa greckiego, in: Religijna mozaika Bałkanów, ed. M. Walczak-Mikołajczakowa, Gniezno 2008, p. 145-151.

Drakulic S., Anti-Turkish obsession and the exodus of Balkan Muslims, „Patterns of Prejudice” 2009, vol. 43, no. 3/4, p. 233-249.

Dymarski M., Konflikty na Bałkanach w okresie ksztattowania się państw narodowych w XIX i na początku XX wieku, Wrocław 2010.

Hirschon R., Crossing the Aegean: an appraisal of the 1923 compulsory population exchange between Greece and Turkey, New York-Oxford 2003.

Holt W., The Balkan reconquista and Turkey's forgotten rufugee crisis, Salt Lake City 2019.

Immig N., Ottoman Past, national discourses on Muslim populations and their architectural legacy in Arta and Thessaly, in: Balkan nationalism(s) and the Ottoman Empire, ed. D. Stamatopoulos, Istanbul 2015, vol. 1, p. 143-158.

Immig N., The „New” Muslim minorities in Greece: between emigration and political participation, 1881-1886, „Journal of Muslim Minority Affairs” 2009, vol. 29, no. 4, p. 511-522. 
Ivanova E., Isliamizirani Balkani. Dinamika na razakazite, Sofija 2014 [Иванова Е., Ислямизирани Балкани. Динамика на разказите, София 2014].

Karpat K., Studies on Ottoman social and political history, Leiden-Boston-Köln 2002.

Katsikas S., European modernity and Islamic reformism among Muslims of the Balkans in the late-Ottoman and post-Ottoman period (1830s-1945), „Journal of Muslim Minority Affairs” 2009, vol. 29, no. 4 , p. $537-543$.

Katsikas S., Millet legacies in a national environment: political elites and Muslim communities in Greece (1830s-1923), in: State-nationalisms in the Ottoman Empire, Greece and Turkey: Orthodox and Muslims, 1830-1945, eds. B. Fortna, S. Katsikas, D. Kamouzis, P. Konortas, Abingdon-New York 2013, p. 47-84.

Konortas P., Les musulmanes de Grèce entre 1821 et 1912, Paris 1980.

Kritikos G., State policy and urban employment of refugees: the Greek case (1923-30), „European Review of History: Revue Européenne d'Histoire" 2000, vol. 7, no. 2, p. 189-206.

Makkarti Dž., Sm'rt i izgnanje: etničeskoto pročistvane na osmanskite miusiulmani (1821-1922), transl. K. Panajotova, Sofija 2010 [Маккарти Дж., Смърт и изгнание: Етническото прочистване на османските мюсюлмани (1821-1922), прев. К. Панайотова, София 2010].

McCarthy J., Muslim in Ottoman Europe: Population from 1880 to 1912, „Nationalities Papers” 2000, vol. 28 , no. 1, p. 29-43.

Obradović Ž., Minorities in the Balkans. 19th and 20th Century, Belgrade 2015.

Palare M., Balkanskite ikonomiki 1800-1914 g. Evolucija bez razvitie, transl. M. Kondakova, Sofija 2005 [Паларе М., Балканските икономики 1800-1914 г. Еволюция без развитие, прев. М. Кондакова, София 2005].

Peçe U.Z., An island unmixed: European military intervention and the displacement of Crete's Muslims, 1896-1908, „Middle Eastern Studies” 2018, vol. 54, no. 4, p. 575-583.

Pentzopoulos D., The Balkan exchange of minorities and its impact on Greece, London 2002.

Poulton H., Changing notions of national identity among Muslims in Thrace and Macedonia: Turks, Pomaks and Roma, in: Muslim identity and the Balkan states, eds. H. Poulton, S. Taji-Farouki, London 1997, p. 82-102.

Poulton H., Islam, Ethnicity and state in the contemporary Balkans, in: Muslim identity and the Balkan States, eds. H. Poulton, S. Taji-Farouki, London 1997, p. 13-32.

Popek K., Muslim emigration from the Balkan Peninsula in the 19th century: a historical outline, „Zeszyty Naukowe UJ. Prace Historyczne" 2019, vol. 146, no. 3, p. 517-533.

Popek K., „A Body Without a Head”. The Elite of the Muslim minority in the Bulgarian lands at the turn of the 20th century, „Balcanica Posnaniensia. Acta et studia” 2018, vol. 25, p. 129-141.

Popek K., Muhadzirowie. Uwagi na temat emigracji muzutmanów z ziem butgarskich na przełomie XIX i XX wieku, „Balcanica Posnaniensia. Acta et studia” 2016, vol. 23, p. 47-69.

Sahara T., Forced ethnic migrations and modernity in the Balkans, in: Forced ethnic migrations in the Balkans: consequences and rebuilding of societies, eds. E. Popova, M. Hajdinjak, Sofia-Tokio 2006, p. 23-41.

Todorov N., Balkanskijat grad XV-XIX vek. Socialno-ikonomičesko I demografsko razvitie, Sofija 1972 [Тодоров Н., Балканският град XV-XIX век. Социално-икономическо и демографско развитие, София 1972].

Tsitselikis K., Old and new Islam in Greece. From historical minorities to immigrant newcomers, LeidenBoston 2012.

Yıldırım O., Diplomacy and displacement reconsidering the Turco-Greek exchange of populations, 1922 1934, New York-London 2006. 